\title{
Constraints perceived about fodder production by the dairy farmers of North Gujarat
}

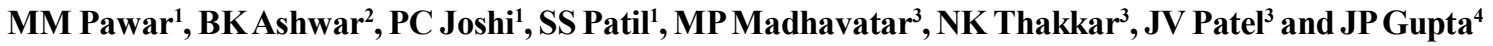

Received: 15 June 2019 / Accepted: 25 July 2019 / Published online: 28 October 2019

(C) Indian Dairy Association (India) 2019

\begin{abstract}
A study was conducted to know the constraints perceived about fodder production by the dairy farmers of north Gujarat. A total of 360 respondents were selected from three districts Banaskantha, Mehsana and Patan representing north Gujarat region in the study. The respondents were interviewed using pre-structured questionnaire to determine the severity of the various constraints about the fodder production. The ranking of constraints was given based on the percentage of severity. The results revealed that 'inadequate credit facilities for purchasing necessary inputs', 'lack of on farm trial and trainings on latest fodder crop cultivation methods' and 'destruction of fodder crops by wild boar' were the first (84.07\%), second (83.43\%) and third $(80.00 \%)$ prominent constraints respectively, perceived by the farmers of north Gujarat about fodder production. Government should ensure that credit and subsidy should be made available to the farmers. Government should also make the efforts to ensure proper training and on field demonstrations about scientific fodder production to farmers through extension activities.
\end{abstract}

Keywords: Constraints, Dairy farmers, Fodder production, North Gujarat

College of Veterinary Science and Animal Husbandry, Sardarkrushinagar Dantiwada Agricultural University, Sardarkrushinagar, Gujarat, India

${ }^{1}$ Department of Animal Nutrition

${ }^{2}$ Department of Veterinary and Animal Husbandry Extension

${ }^{3}$ Department of Livestock Production and Management

${ }^{4}$ Department of Animal Genetics and Breeding

JP Gupta $(\bowtie)$

Department of Animal Genetics and Breeding, College of Veterinary Science and Animal Husbandry, Sardarkrushinagar Dantiwada Agricultural University, Sardarkrushinagar, Gujarat, India

E-mail: jp.prakash01@gmail.com
The livestock feed and fodder can be divided into two broad categories- roughages and concentrates. Roughages are further classified into green fodder and dry fodder. Green fodder is cultivated and harvested for feeding the animals in the form of forage (cut green and fed fresh), silage (preserved under anaerobic condition) and hay (dehydrated green fodder). The estimates of fodder production in the country vary widely. Fodder production is depending on various factors like cropping pattern followed, climatic condition of the area as well as the socio-economic conditions of the household and type of livestock reared. Feeding of forage to dairy animals is essential for economic and sustainable milk production and reports indicate that 4 to $5 \mathrm{~kg}$ per day milk yield can be sustained on all forage rations. Forage crops provide nutritional and palatable green forage all the year round. Maximization of forage in the diet of dairy animal makes their ration much cheaper as compared to concentrate based ration.

Adequate availability of quality fodder is essential for enhancing livestock productivity. Scarcity of fodder in North Gujarat may be one of the primary reasons for gradual depletion of Kankrej cattle population (Ekka et al. 2014). For this, there is need to target at least ten percent of the cultivable land for growing fodder crops. There is tremendous pressure on available total feed and fodder, because of increasing livestock population and decreasing land available for fodder production. At present, there is huge gap between demand and supply of animal feed and fodder. As per recent study, the country faces a net deficit of $35.6 \%$ green fodder, $10.95 \%$ dry crop residues and $44 \%$ concentrate feeds (IGFRI VISION 2050 Document, 2013). It is matter of prime concern to bridge this gap. Hence, the efforts should be directed to intensify fodder production per unit area per unit time (Ahmed et al. 2017). However, the farmers face several constraints in cultivation of forage crops. These constraints perceived by the farmers should be identified and addressed to increase the production and availability of fodder. Therefore, the present study was planned to know the constraints perceived about fodder production by the dairy farmers of north Gujarat.

The study comprised three districts of North Gujarat region namely Banaskantha, Patan and Mehsana. These were selected purposively considering maximum livestock density in these 
districts in North Gujarat. Thereafter, two phase stratified random sampling was done. Two tehsils were selected randomly from each identified district and from each selected tehsil, three villages were selected randomly. Twenty fodder growing dairy farmers from each village were selected. Thus, total 360 dairy farmers (120 farmers per district) constituted the sample size for this study.Total1 8 constraints related to fodder production were identified viz. 1) Inadequate credit facilities for purchasing necessary inputs, 2) Inadequate reliable input suppliers in the local market, 3) Necessary inputs are not available in time, 4) Non-availability of land for cultivation of fodder crops, 5) Poor infrastructure facilities for fodder storage, 6) Destruction of fodder crops by wild boar, 7) Destruction of fodder crops by
Nilgai, 8) Losses in fodder crops due to trespassing by animals, 9) Destruction of stored fodder crops by rats/termites, 10) Physical losses in fodder crops due to storage in open space, 11) Nutrient losses in fodder crops due to storage in open space, 12) Scarcity of water for fodder crop irrigation, 13) Scarcity of improved fodder seeds, 14) Poor knowledge on latest know-how of cultivated fodder crops, 15) Lack of knowledge about conservation of excess fodder, 16) Lack of knowledge about unconventional fodder sources, 17) Lack of knowledge about presence of anti-nutritional factors in unconventional fodder sources and 18) Lack of on farm trial and trainings on latest fodder crop cultivation methods. All the 360 farmers were interviewed using pre-structured questionnaire to determine the severity of above mentioned

Table 1 Constraints perceived by the dairy farmers of Banaskantha, Patan and Mehsana districts of north Gujarat about fodder production $(\mathrm{n}=120)$

\begin{tabular}{lcc}
\hline Sr. No.Constraints & Severity (\%) \\
\hline District: Banaskantha & Rank \\
1) $\quad$ Inadequate credit facilities for purchasing necessary inputs & 88.61 \\
2) $\quad$ Necessary inputs are not available in time & 79.44 \\
3) $\quad$ Lack of on farm trial and trainings on latest fodder crop cultivation methods & 78.61 \\
& District: Patan & I \\
1) $\quad$ Inadequate credit facilities for purchasing necessary inputs & 95.28 \\
2) $\quad$ Lack of on farm trial and trainings on latest fodder crop cultivation methods & 85.83 \\
3) $\quad$ Lack of knowledge about presence of anti-nutritional factors in unconventional & 84.44 \\
& fodder sources & I \\
District: Mehsana & II \\
1) Destruction of fodder crops by wild boar & III \\
2) Lack of on farm trial and trainings on latest fodder crop cultivation methods & 89.17 \\
3) Non-availability of land for cultivation of fodder crops & 82.53 \\
\hline
\end{tabular}

Table 2 Constraints perceived by the dairy farmers of north Gujarat region about fodder production $(n=360)$

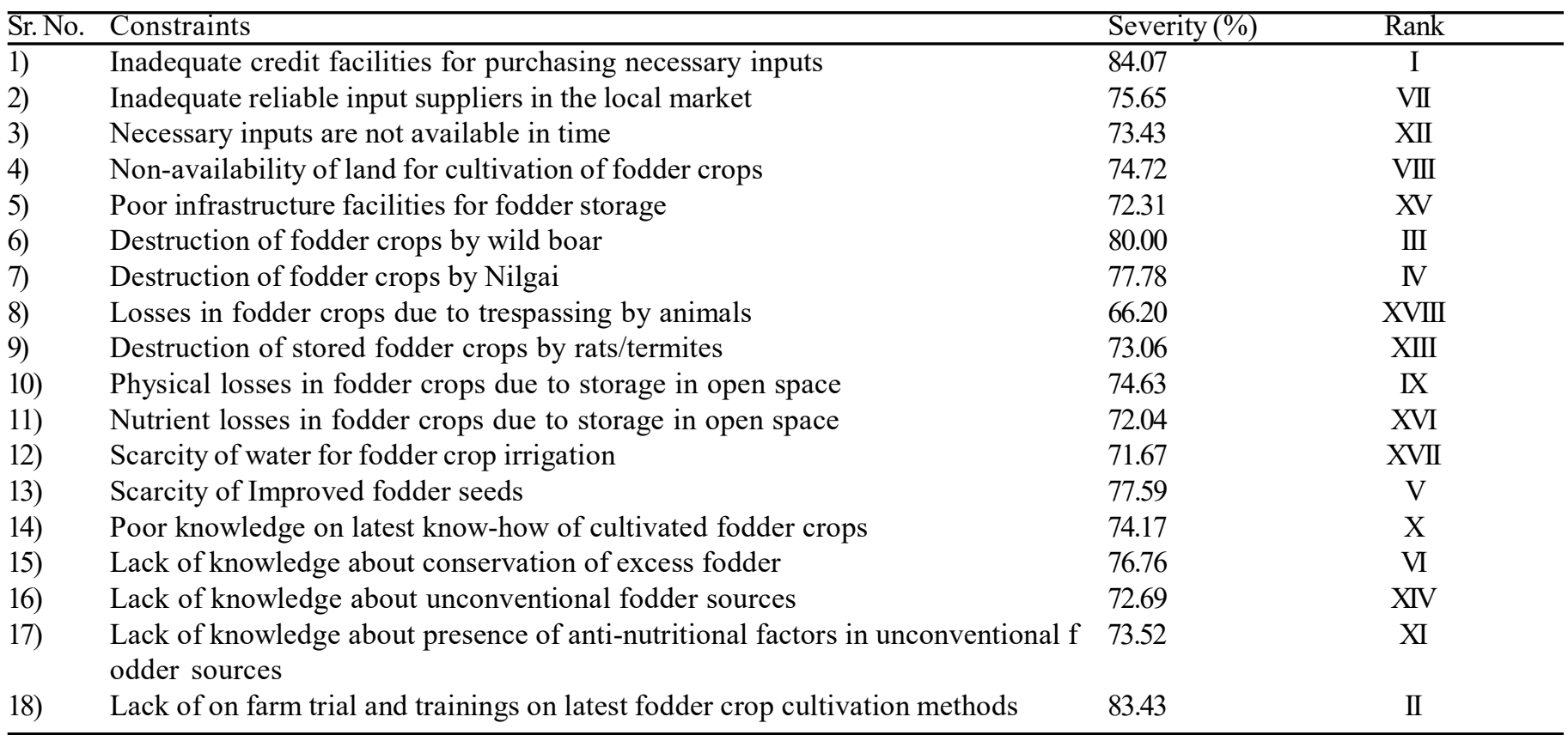


constraints about the fodder production. The ranking of constraints was given based on the percentage of severity.

Constraints perceived about fodder production by the dairy farmers of Banaskantha, Patan and Mehsana districts of north Gujarat are given in table 1. The results revealed that the most important constraints about fodder production by the dairy farmers of Banaskantha district was 'inadequate credit facilities for purchasing necessary inputs' which was perceived as very serious constraints with first rank $(88.61 \%)$. 'Necessary inputs are not available in time' was found to be the second ranked constraint (79.44\% severity). The third rank constraint was 'lack of on farm trial and trainings on latest fodder crop cultivation methods with severity of 78.61 per cent. In Patan district, it was found that $95.28 \%$ of farmer- respondents had 'inadequate credit facilities for purchasing necessary input' is the primary constraint similar to that of farmers of Banaskantha district. The second constraint of 'lack of on farm trial and trainings on latest fodder crop cultivation methods' was faced by farmers with severity of 85.83 per cent. 'Lack of knowledge about presence of antinutritional factors in unconventional fodder sources' was the third ranked constraint with severity of 84.44 per cent. The 'destruction of fodder crops by wild boar' was first ranked constraint with severity of 89.17 per cent, followed by 'Lack of on farm trial and trainings on latest fodder crop cultivation methods' ranked second $(85.83 \%)$ and 'non-availability of land for cultivation of fodder crops' ranked third (82.50\%) constraint in Mehsana district. Presence of wild boars in large numbers in Mehsana district may have also aggravated the problem. This difference in constraints faced by livestock owners in these districts might be due to lack of self interest by livestock owners and prompt response of local bodies and administration on above mentioned aspects of channelizing of credit facilities for fodder production.

The overall constraints perceived by the dairy farmers of north Gujarat area about fodder production given in table 2. The results revealed that 'inadequate credit facilities for purchasing necessary inputs' $(84.07 \%)$, 'lack of on farm trial and trainings on latest fodder crop cultivation methods' $(83.43 \%)$ and 'destruction of fodder crops by wild boar' $(80.00 \%)$ were first, second and third rank constraints, respectively, perceived by the farmers of north Gujarat area about fodder cultivation.

Enhanced investments in agriculture and animal husbandry sectors could achieve a higher annual growth rate of cultivated fodder for livestock. Similar to the present findings, Meena et al. (2017) reported that the most important constraint was 'inadequate credit facilities for purchasing necessary inputs' which was perceived as very serious constraints with first rank (84.02\%). This might be due to lack of awareness among the farmers about the existing banking facilities in the rural areas. About 80 percent respondents in Banaskantha district have constraint of 'necessary inputs are not available in time'. Banerjee and Biradar
(2016) found that farmers have difficulty in accessing planting material of fodder crops. The findings of the present study are in the lines of the findings of the Meena et al. (2017). Although, farmers try to cultivate green fodder even in a small plot to make sure the fodder is available for the livestock. Due to lesser size of land holdings, the farmers unable to get enough land for other crops and devote more attention towards food grain crops. As food grains and pulses are directly related to livelihood of farmers and they find that livestock can survive on other left crop residues, so they give less priority to fodder crops. Land availability is one of the major factors determining fodder cultivation (Kumar et al. 2018).

In agreement with the present findings, Meena et al. (2017) found that 'lack of demonstration and training was ranked third constraint with severity of 75.69 per cent. Moreover, Suman et al (2017) reported that the main reason for less knowledge in farmers of fodder production technologies were lack of awareness about improved technologies. It may be due to the lack of government policies on fodder development, improper execution of the fodder development programmes because of lack of sufficient numbers of operational staffs, less priority to fodder development and unnecessary political inferences. There is a need to have an ensuring system through which information can be disseminated. The government may encourage the farmers through awareness campaign, sangosthi, literature distribution and demonstration conducted by the scientists, subject matter specialists, etc. for taking-up the scientific fodder production. The need based dissemination of knowledge with the help of different media can be important strategy. The electronic media enabled extension systems are acting as a key agent for changing agrarian situation and farmers' lives by improving access to information and sharing knowledge (Mohanakumara and Biradar, 2018). Meena et al. (2017) observed that the 'lack of knowledge about unconventional fodder sources' was found to be the fourth ranked constraint which had 73.05 per cent severity. The reason for lack of knowledge among the farmers can be explained by lack of adequate attention of the farmers in the dairying and unconventional fodder sources. Though government has implemented some of fodder conservation and management schemes, yet fodder scarcity is the major concern of the hour (Earagariyanna et al. 2017).

\section{Conclusions}

Inadequate credit facilities for purchasing necessary inputs and lack of on farm trial and trainings on latest fodder crop cultivation methods were the most serious constraints perceived by the farmers of north Gujarat related to fodder production. Government should ensure that credit and subsidy should be made available to the farmers and also make the efforts to provide proper training and on field demonstrations about scientific fodder production to farmers through extension activities. 


\section{References}

Ahmed S, Sahay G, Sridhar K, Singh S, Saxena P, Roy AK (2017) Improved Forage Crop Varieties of IGFRI. Technical Bulletin. Indian Grassland and Fodder Research Institute, Jhansi, Uttar Pradesh, India

Banerjee P, Biradar N (2016) Socio-economic profile of perennial fodder growers and the constraints faced by them in cultivation. J Farm Sci 29: 466-469

Earagariyanna M, Venkayala J, Kammardi S, Sriramaiah M, Kiran M (2017) Fodder resource management in India- A critical analysis. Int J Livest Res 7: 14-22

Ekka P, Gupta JP, Pandey DP, Prajapati KB, Patel JB, Shah RR (2014) Genetic analysis of first production and reproduction traits in Kankrej cattle. Indian J Dairy Sci 67: 236-239

IGFRI VISION 2050 (2013) Technical Bulletin. Indian Grassland and Fodder Research Institute, Jhansi, Uttar Pradesh, India
Kumar S, Kalamkar SS, Parihar TB (2018) Constraints facing livestock feed and fodder traders: Evidence from Gujarat in India. Int J Pure App Biosci 6: 208-213

Meena DK, Sankhala G, Kant K, Prasad K (2017) Constraints perceived by the dairy farmers about fodder production in Rajasthan state of India. Indian J Dairy Sci 70: 244-246

Mohanakumara V, Biradar N (2018) Socio-economic profile of livestock farmers and their level of symbolic adoption of fodder production technology as influenced by e-training tools. J Pharmacogn Phytochem 7: 2606-2610

Suman M, Kumar V, Kumar A (2017) Study of farmers' perception constraints for lesser adoption of fodder production technologies and ways to improve the adoption in Bundelkhand region. Agric Sci Digest 37: 166-167 